\title{
DIREITO PENAL DA SEGURIDADE SOCIAL E DIREITO PENAL PREVIDENCIÁRIO: CONTRIBUTO PARA SUA DELIMITAÇÃO FRENTE AO DIREITO PENAL ECONÔMICO
}

\section{SOCIAL SECURITY CRIMINAL LAW AND SOCIAL TAX CRIMINAL LAW: CONTRIBUTION FOR ITS DELIMITATION BEFORE THE ECONOMIC CRIMINAL LAW}

\section{Ramiro Gomes von Saltiel ${ }^{1}$}

Resumo: Este estudo tem como objeto os crimes contra a Seguridade Social, que podem ser chamados também crimes previdenciários. O problema a se enfrentar é qual o status epistemológico do direito penal da Seguridade Social; se se trata de uma disciplina autônoma ou, quiçá, um ramo do direito penal econômico. O método de pesquisa é o hipotético-dedutivo, partindo-se da premissa maior para a menor, mediante técnica de revisão bibliográfica e jurisprudencial. A hipótese ventilada é que o direito penal da Seguridade Social não constitui disciplina autônoma de estudo; da mesma forma, não se trata de mero ramo do direito penal econômico, tendo em vista que há também crimes tradicionais abarcados pelo conceito, de modo que o verdadeiro critério para se aferir a criminalidade em questão é a ofensa aos bens jurídico-penais tutelados pelo direito penal da Seguridade Social.

Palavras-chave: Direito Penal. Direito Penal Previdenciário. Crimes contra a Seguridade Social. Direito Penal Econômico.

Abstract: This study has as object the crimes against the Social Security, which may be called also as Security tax crimes. The problem to be faced is what is the epistemological status of the Social Security criminal law; if it is an autonomous discipline or, maybe, a branch of the economic criminal law. The method of research is the hypothetical-deductive, starting from the major premise to the minor, through the technique of bibliographic and jurisprudential revision. The hypothesis is that the Social Security criminal law do not constitute an autonomous discipline of study; also, it is not a simple branch of the economic criminal law, given that there are also traditional crimes embraced by the concept, so that the true criterion to measure the criminality in question is the offense to criminal law objects protected by the Social Security criminal law.

Keywords: Criminal Law. Social Security Criminal Law. Crimes against Criminal Security. Economic Criminal Law.

\footnotetext{
${ }^{1}$ Mestre em ciências criminais pelo programa de pós-graduação em ciências Criminais da PUCRS (bolsista PROEX-CAPES). Especialista em ciências penais pela PUCRS. Realizou Iniciação Científica junto ao Laboratório de Ciências Criminais do IBCCRIM (Porto Alegre/RS, edição de 2017). Tem experiência de pesquisa em temas de teoria geral do delito, direito processual penal e crimes tributários e contra a seguridade social no Brasil. Participou de diversos eventos acadêmicos, tendo também publicado textos científicos em revistas e livros. Tem experiência na docência, como estagiário docente, tendo acompanhado o prof. Dr. Marcelo Almeida Ruivo, na PUCRS. Advogado e pesquisador.
} 
Recebido em: 19/06/2021

Aceito para publicação em: 07/10/2021 


\section{INTRODUÇÃO}

Os crimes contra a Seguridade Social estão disciplinados na parte especial do Código Penal brasileiro, tendo sido majoritariamente introduzidos pela lei $\mathrm{n}$. $9.983 / 2000$. Esta lei tipificou diversas condutas, sendo que nem todas guardam relação entre si; há crimes tributários, como os de não-recolhimento e de sonegação de contribuição previdenciária (arts. 168-A e 337-A, do CP), crimes informáticos, como de inserção de dados falsos nos sistemas da Administração Pública (art. 313-A, CP) e inserção de dados falsos na CTPS (art. 297, § 30, II, CP), dentre outros.

A dinâmica desses crimes, contudo, é bastante diversa, tendo em vista que alguns deles não são destinados apenas à proteção da Seguridade Social, como o caso do estelionato contra entes públicos (art. 171, § 30, CP); da mesma forma, os crimes de natureza tributária têm conexões, p. ex., com a lei dos crimes tributários (lei n. 8.137/90) e a lei referente a extinção de punibilidade pelo pagamento dos débitos (lei n. 9.249/95).

O objetivo do presente escrito é delimitar quais dos crimes previstos no Código Penal estão destinados à proteção dos bens jurídicos da Seguridade Social, e qual a sua relação com a disciplina do direito penal econômico. Trata-se de um problema bastante delimitado, mas que, por vezes, causa alguma confusão entre os aplicadores do direito, por haver pouca clareza entre as fronteiras dos crimes contra a Administração Pública e os crimes tributários; ou ainda destes últimos com os crimes contra a Seguridade Social ( $v$.g. a Jurisprudência do STF em aceitar o princípio da insignificância contra crimes tributários, mas não contra os crimes contra a Previdência Social).

A hipótese maior ora levantada é a de que o direito penal econômico constitui disciplina autônoma dentro do direito penal, tendo algumas particularidades com relação a ele. Neste contexto, surge uma hipótese menor, de que há uma criminalidade destinada à Seguridade Social; contudo, estes crimes constituem apenas um ramo do direito penal econômico, não constituindo uma disciplina autônoma. 


\section{A DISCIPLINA DO DIREITO PENAL ECONÔMICO}

Em brevíssimas linhas, sabe-se que as relações entre direito e economia se fortaleceram nas últimas décadas. O Estado, a partir de determinado momento, passou a ser chamado em mais áreas de atuação se comparado à sua face negativa projetada pelas reformas iluministas; dentre essas áreas, estava a realização e prestação de direitos sociais, o que está irremediavelmente ligado à economia. ${ }^{2}$

Essa nova figura do Estado Social, provedor, que passou a intervir com mais frequência na sociedade, passou a se equipar com novos aparelhos estatais, inclusive aqueles econômicos; da mesma forma, as prestações estatais levantaram a questão de que todo o direito possui algum tipo de custo para o Estado (HOLMES; SUNSTEIN, 1999, p. 40). Logo, a realização do direito é também uma realização econômica.

Também o direito penal foi atingido por essa nova dinâmica prestacional dos direitos, aumentando-se as suas relações com a economia, e também com a política. ${ }^{3}$ Alguns tipos de ilícitos passaram a ser considerados cada vez mais graves, dignos daquela forma mais gravosa de sanções que o direito pode oferecer.

No Brasil, a Constituição de 1988 é um verdadeiro marco a respeito desses novos espaços de criminalização. A Carta soma diversas figuras incriminatórias, desde a retenção dolosa de salário até a questionável figura dos crimes hediondos. ${ }^{4}$

Começou-se a investigar qual a categoria desse novo tipo de intervenção, que também era penal, teria; evidentemente, era um fenômeno diferente do direito penal tradicional, ou clássico. Mesmo assim, não deixava de ter uma unidade com esse mesmo direito penal clássico, compartilhando com ele seus principais fundamentos, como o princípio da legalidade e ofensividade; da mesma forma o

\footnotetext{
Para uma análise sobre as relações entre a Constituição e a economia, obra de referência é a de Vital Moreira (1979, p. 20); e, em dogmática jurídico-penal, v. Figueiredo Dias (2000, p. 18 e 38), que aponta esta maior interferência, em Portugal, após a I Guerra, e fala em Estado de Direito Material, envolvido com a realização das tarefas sociais do Estado; no Brasil, v. Schmidt (2018, p. 33).

3 V. Jorge de Figueiredo Dias. Op. cit., p. 14.

4 Uma análise dos mandados na Constituição brasileira em: Feldens $(2005$, p. 61$)$ V. também as críticas de Dolcini e MarinuccI (1994, p. 351), para quem a CF foi demasiado ampla nesses mandamentos.
} 
processo judicial voltado a esse tipo de criminalidade, com princípios como a presunção de inocência.

Das sanções de âmbito administrativo, são conhecidos os chamados crimes de polícia, que visavam a proteção dos direitos subjetivos dos cidadãos em uma esfera mais imediata e menos gravosa, que acabariam transformando-se no conceito de contravenção. Não à toa, mesmo esses fatos menos ofensivos acabariam incluindo condutas, como, por exemplo, o contrabando e o descaminho. ${ }^{5}$

Contudo, não se está a falar desse tipo de sanções: seja contravenções, contra ordenações (Portugal) ou simples ilícitos administrativos. Não. Trata-se, efetivamente de um direito penal, que não é inteiramente novo, mas que não cabe na moldura que classicamente se Ihe atribui. Passou-se a se falar em um direito penal econômico, questionando-se se seria uma disciplina autônoma, ou um mero ramo subordinado ao direito penal tradicional.

O conceito de disciplina vem como para catalogar uma realidade pelo rigor e acerto de "critérios metodológicos racionalmente sustentados" (COSTA, 2003, p. 14). ${ }^{6} \mathrm{O}$ direito penal econômico, é, portanto, uma realidade normativa e disciplinar que se distingue do direito penal "clássico"; $;$ tendo aquele primeiro alguma autonomia sobre o direito penal clássico, sem, contudo, deixar de tê-lo como o seu fundamento (COSTA, 2003, p. 16). ${ }^{8}$

Assim, deve o direito penal econômico possuir metodologia, objeto e princípios próprios (COSTA, 2003, p. 19); da mesma forma os bens jurídico-penais protegidos por este diferenciado ramo do direito são diferentes daqueles do direito penal clássico, pois referem-se a valores supraindividuais (COSTA, 2003, p. 38). ${ }^{9}$ Esses bens possuem igualmente relevância constitucional, estando vinculados ao

5 Cfr. Figueiredo Dias (2000, p. 17, nota 20) era geral na doutrina a noção de que essas figuras constituiriam, no máximo, contravenções ou infrações não-penais, o que não foi seguido pelo legislador do CP português de 1852.

6 Sobre direito penal secundário, direito penal econômico e direito penal administrativo econômico, v. Dias (2000, p. 14).

7 Cfr. COSTA (2003, p. 16), não se pode confundir a disciplina que visa estudar os objetos com os próprios objetos que se visa proteger por aquelas condutas ditas anti-econômicas.

8 Semelhante: Dias $(2000$, p. 36) ressalta que há "relativa autonomia do direito penal secundário no corpo, fundamentalmente unitário, do direito penal", até mesmo pela especificidade dos bens jurídico-penais protegidos (grifo do autor), e destaca ainda que vale, para o direito penal econômico, os princípios do direito penal clássico, como legalidade, culpabilidade etc. (p. 46). No Brasil, v. Schmidt (2018, p. 73).

9 V. também Dias (2000, p. 40) e Schmidt (2018, p. 89). 
desenvolvimento da personalidade humana, tendo-a como seu fundamento e como seu fim último. ${ }^{10}$

\section{CRIMES PREVIDENCIÁRIOS NO BRASIL}

No Brasil, os crimes previdenciários não constituem novidade. 0 não-recolhimento de tributo do empregado, descontado pelo patrão, existe pelo menos desde 1937, quando o DL n. 65 equiparou, em seu art. 50, essa conduta às penas do crime de apropriação indébita (furto impróprio), então previsto no art. 331, no 2 da CLP. A esta figura, sucederam muitas outras, com destaque ao art. 86 da LOPS, o art. $2^{\circ}$, II da lei n. 8.137/90 e o art. 95, $d$ da lei n. 8.212/91. ${ }^{11}$ Da mesma forma, o estelionato previdenciário (art. 171, § 30, CP) existe desde 1940, tendo sua redação original até o momento. ${ }^{12}$

Quanto à lei n. 9.983/2000, no curso de seus debates legislativos (enquanto ainda PL n. 933/99) houve uma certa mudança de rumos, uma vez que muitos dos crimes ali propostos, incialmente, referiam-se exclusivamente à proteção da Seguridade Social. Contudo, promulgada a lei, substituiu-se, em diversos tipos, a figura da Previdência pela da Administração Pública em geral, em tom generalizante e demasiado amplo. ${ }^{13}$

De modo geral, ao falar-se em crimes previdenciários, fala-se nos seguintes tipos penais: apropriação indébita previdenciária (art. 168-A, CP), sonegação de contribuições previdenciárias (art. 337-A, CP), falsificação previdenciária (art. 297, §§

10 Dias (2000, p. 42); Estellita (2001a, p. 176); Fiandaca (1982, p. 71); Schmidt (2018, p. 89).

11 De um modo geral, a doutrina que se debruçou na análise do tipo penal de não-recolhimento buscou compreender a sua equiparação com a apropriação indébita tradicional; enquanto que, no caso de sonegação de contribuições previdenciárias, normalmente tratava-se do crime de sonegação de tributo, sem maior atenção à sonegação previdenciária adicionada pelo DL n. 66/66 ao art. 155, I da LOPS. V. Fragoso (1965, p. 6); Pimentel (1973, p. 324).

12 Nelson Hungria (1958, p. 252) justificava a agravação da pena pela afetação de "interesse da coletividade ou de indefinido número de pessoas".

13 Isto ocorreu, por exemplo, com os arts. 313-A e 313-B, CP, que, em projeto de lei, referiam-se a "sistemas informáticos ou bancos de dados da previdência social", já que esta última passava por um processo de informatização; contudo, a redação final da lei, trouxe, genericamente "sistemas informatizados ou bancos de dados da Administração Pública" (art. 313-A, CP). Sobre isto, v. Saltiel (2020, p. 76). 
$3^{\circ}$ e $4^{\circ}, \mathrm{CP}$ ) e estelionato previdenciário (art. 171, CP). ${ }^{14}$ Neste trabalho, adiciona-se ainda os crimes informáticos de inserção de dados falsos em sistema de informações (art. 313-A, CP) e modificação ou alteração não autorizada de sistema de informações (art. 313-B, CP), conforme passa-se a expor.

Há os crimes tributários de 1) não-recolhimento de contribuições previdenciárias (art. 168-A, $\S 10, \mathrm{CP}$ ) e de 2) sonegação de contribuições previdenciárias (art. 337-A, CP). ${ }^{15}$ Essas figuras correspondem, essencialmente, aos arts. $2^{\circ}$, II e $1{ }^{\circ}$, caput e incisos, da lei n. $8.137 / 90,{ }^{16}$ e, sem dúvida, trata-se de duas das figuras mais vistas em doutrina e Jurisprudência nacional e internacional na matéria.

Há os variados crimes de 3) falsificação de documentos públicos, relacionados à Previdência Social (art. $297 \S \S 3^{\circ}$ e incisos, e 40, CP). ${ }^{17}$ Tratam-se de

14 V. Gomes; Borsio (2014, p. 25 e s.); Maciel Filho (2004, p. 75).

15 "Art. 168-A. Deixar de repassar à previdência social as contribuições recolhidas dos contribuintes, no prazo e forma legal ou convencional: Pena - reclusão, de 2 (dois) a 5 (cinco) anos, e multa. § 1ㅇ Nas mesmas penas incorre quem deixar de: I - recolher, no prazo legal, contribuição ou outra importância destinada à previdência social que tenha sido descontada de pagamento efetuado a segurados, a terceiros ou arrecadada do público"; "Art. 337-A. Suprimir ou reduzir contribuição social previdenciária e qualquer acessório, mediante as seguintes condutas: I - omitir de folha de pagamento da empresa ou de documento de informações previsto pela legislação previdenciária segurados empregado, empresário, trabalhador avulso ou trabalhador autônomo ou a este equiparado que lhe prestem serviços; II - deixar de lançar mensalmente nos títulos próprios da contabilidade da empresa as quantias descontadas dos segurados ou as devidas pelo empregador ou pelo tomador de serviços; III - omitir, total ou parcialmente, receitas ou lucros auferidos, remunerações pagas ou creditadas e demais fatos geradores de contribuições sociais previdenciárias: Pena - reclusão, de 2 (dois) a 5 (cinco) anos, e multa". Ressalte-se que o art. $168-\mathrm{A}, \S 10, \mathrm{CP}$, possui ainda duas outras figuras típicas nos incisos II e III. Contudo, devido à baixa aplicação dessas figuras, não comentaremos a seu respeito.

16 "Art. $2^{\circ}$ Constitui crime da mesma natureza: II - deixar de recolher, no prazo legal, valor de tributo ou de contribuição social, descontado ou cobrado, na qualidade de sujeito passivo de obrigação e que deveria recolher aos cofres públicos; [...]. Pena - detenção, de 6 (seis) meses a 2 (dois) anos"; Art. $1^{\circ}$ Constitui crime contra a ordem tributária suprimir ou reduzir tributo, ou contribuição social e qualquer acessório, mediante as seguintes condutas: I - omitir informação, ou prestar declaração falsa às autoridades fazendárias; II - fraudar a fiscalização tributária, inserindo elementos inexatos, ou omitindo operação de qualquer natureza, em documento ou livro exigido pela lei fiscal; III - falsificar ou alterar nota fiscal, fatura, duplicata, nota de venda, ou qualquer outro documento relativo à operação tributável; IV - elaborar, distribuir, fornecer, emitir ou utilizar documento que saiba ou deva saber falso ou inexato; $V$ - negar ou deixar de fornecer, quando obrigatório, nota fiscal ou documento equivalente, relativa a venda de mercadoria ou prestação de serviço, efetivamente realizada, ou fornecê-la em desacordo com a legislação. Pena - reclusão de 2 (dois) a 5 (cinco) anos, e multa".

17 "Art. 297. Falsificar, no todo ou em parte, documento público ou alterar documento público verdadeiro: Pena - reclusão, de dois a seis anos, e multa. [...] $\S 3^{\circ}$ Nas mesmas penas incorre quem insere ou faz inserir: I - na folha de pagamento ou em documento de informações que seja destinado a fazer prova perante a previdência social, pessoa que não possua a qualidade de segurado obrigatório; II - na Carteira de Trabalho e Previdência Social do empregado ou em 
ilícitos de falsidade, com a mesma dinâmica do crime de falsidade ideológica, em que há alteração substancial do conteúdo do documento, sendo crítica frequente na doutrina a sua tipificação errada como parágrafo do crime de falsidade material (BITENCOURT, 2020, p. 655-656). De modo geral, aponta-se a fé pública como bem jurídico-penal tutelado (MACIEL FILHO, 2004, p. 125), falando-se, também na proteção da previdência (GOMES; BORSIO, 2014, p. 97) e da organização do trabalho (PAULSEN, 2017, p. 378). Ademais, veja-se o art. 49 da $\mathrm{CLT}_{1}{ }^{18}$ adicionado pelo DL n. 229/67 equipara algumas condutas à falsidade ideológica do art. 299 do Código Penal, estas relacionadas não à inserção de informações inverossímeis na CTPS, mas com relação à falsificação da própria CTPS ou de outros documentos.

Há o 4) crime patrimonial do estelionato previdenciário (art. 171, § $\left.3^{\circ}\right) .{ }^{19}$ Esta figura, o crime mais antigo em vigor, originário do $D L$ n. 2.848/40, é também a mais abrangente, abarcando o patrimônio de qualquer órgão ou entidade estatal da União. Protege-se o patrimônio de qualquer corpo estatal que seja financeiramente prejudicado pelo enriquecimento ilícito do agente, como a obtenção fraudulenta de empréstimo junto à Caixa Econômica Federal, por exemplo, crime praticado em "detrimento do patrimônio da União, de suas autarquias ou empresas federais". ${ }^{20}$

documento que deva produzir efeito perante a previdência social, declaração falsa ou diversa da que deveria ter sido escrita; III - em documento contábil ou em qualquer outro documento relacionado com as obrigações da empresa perante a previdência social, declaração falsa ou diversa da que deveria ter constado. $\S 4^{\circ}$ Nas mesmas penas incorre quem omite, nos documentos mencionados no $\S 3 \circ$, nome do segurado e seus dados pessoais, a remuneração, a vigência do contrato de trabalho ou de prestação de serviços".

18 "Art. 49 - Para os efeitos da emissão, substituição ou anotação de Carteiras de Trabalho e Previdência Social, considerar-se-á, crime de falsidade, com as penalidades previstas no art. 299 do Código Penal: I - Fazer, no todo ou em parte, qualquer documento falso ou alterar o verdadeiro; II - Afirmar falsamente a sua própria identidade, filiação, lugar de nascimento, residência, profissão ou estado civil e beneficiários, ou atestar os de outra pessoa; III - Servir-se de documentos, por qualquer forma falsificados; IV - falsificar, fabricando ou alterando, ou vender, usar ou possuir Carteira de Trabalho e Previdência Social assim alteradas; V - Anotar dolosamente em Carteira de Trabalho e Previdência Social ou registro de empregado, ou confessar ou declarar em juízo ou fora dele, data de admissão em emprego diversa da verdadeira".

19 "Art. 171 - Obter, para si ou para outrem, vantagem ilícita, em prejuízo alheio, induzindo ou mantendo alguém em erro, mediante artifício, ardil, ou qualquer outro meio fraudulento: Pena reclusão, de um a cinco anos, e multa, de quinhentos mil réis a dez contos de réis. [...] § $3^{\circ}-\mathrm{A}$ pena aumenta-se de um terço, se o crime é cometido em detrimento de entidade de direito público ou de instituto de economia popular, assistência social ou beneficência".

20 Paulsen (2017, p. 192). Na Jurisprudência, v.: "O réu de forma livre e consciente, tentou obter para si, vantagem ilícita em prejuízo da Caixa Econômica Federal - CEF, consistente no recebimento indevido do FGTS, apresentando para tanto, documentos falsificados, o que justifica condenação pelo crime de estelionato" BRASIL. Tribunal Regional Federal da 4a Região. Apelação Criminal n. 
Por último, adicione-se os crimes informáticos de 5) inserção de dados falsos em sistema de informações (art. 313-A, CP) e 6) modificação ou alteração não autorizada de sistema de informações (art. 313-B, CP), sendo ambos crimes próprios, praticados por funcionário público. ${ }^{21} \mathrm{~A}$ primeira figura criminaliza o servidor que altere determinado sistema informático para que não corresponda com a verdade dos fatos, com o fim de obtenção de vantagem indevida; trata-se de um espelho do estelionato contra entidade pública, sendo inclusive comum associações criminosas em que o funcionário responde pelo art. 313-A, CP, e o terceiro, pelo art. 171, § 30, CP (PAULSEN, 2017, p. 153 e 196). De todo modo, ambos os tipos penais são abrangentes, não se limitando ao âmbito dos sistemas informáticos da Previdência Social, tendo optado o legislador por expandir injustificadamente a proteção a toda a Administração Pública. ${ }^{22}$

Há ainda outras figuras que, dada a sua abrangência, podem ou não ser praticadas em desfavor da Seguridade Social, como os arts. 153, § 10-A, CP e 296, § 10, III, CP, ambos adicionados pela lei n. 9.983/2000, mas que não serão aqui analisadas. ${ }^{23}$

Assim, surge o problema: o que torna esses tipos penais voltados à proteção da Seguridade Social? Alguns critérios devem ser oferecidos para responder essa pergunta, considerando a natureza de norma penal em branco atinente aos crimes previdenciários em geral. ${ }^{24} \mathrm{O}$ primeiro deles é compreender a dinâmica da Previdência Social dentro do Sistema de Seguridade Social brasileiro; e, a partir

5004397-05.2014.4.04.7008. Rel. des. Carlos Eduardo Thompson Flores Lenz. Julgado em: 03 mar. 2021.

21 "Art. 313-A. Inserir ou facilitar, o funcionário autorizado, a inserção de dados falsos, alterar ou excluir indevidamente dados corretos nos sistemas informatizados ou bancos de dados da Administração Pública com o fim de obter vantagem indevida para si ou para outrem ou para causar dano: Pena - reclusão, de 2 (dois) a 12 (doze) anos, e multa"; "Art. 313-B. Modificar ou alterar, o funcionário, sistema de informações ou programa de informática sem autorização ou solicitação de autoridade competente: Pena - detenção, de 3 (três) meses a 2 (dois) anos, e multa. Parágrafo único. As penas são aumentadas de um terço até a metade se a modificação ou alteração resulta dano para a Administração Pública ou para o administrado".

22 V. NR n. 12.

23 Veja-se o art. 153, § 10-A, CP: "Divulgar, sem justa causa, informações sigilosas ou reservadas, assim definidas em lei, contidas ou não nos sistemas de informações ou banco de dados da Administração Pública: Pena - detenção, de 1 (um) a 4 (quatro) anos, e multa".

24 As normas penais em direito penal econômico são, seguidamente, daquele gênero de normas penais em branco, cujo conteúdo possui natureza extra-penal, amiúde de direito administrativo; cfr. Figueiredo Dias (2000, p. 49). 
disso, analisar se os chamados crimes previdenciários ofendem apenas a Previdência, ou Sistema como um todo.

\subsection{Seguridade Social e Previdência Social}

Na Constituição de 1988, o Sistema de Seguridade Social foi positivado e elevado à categoria de direito fundamental (SARLET, 2015, p. 267 e 317), sendo disciplinado no art. 193 e seguintes, além de estar previsto como direito fundamental social e do trabalho, nos arts. $6^{\circ}$ e 70 da $\mathrm{CF}^{25}$

Já o art. 194, CF, prevê os três pilares do Sistema de Seguridade Social: saúde, previdência e assistência social. Não cabe aqui uma delimitação do conceito e da função de cada um desses pilares; a questão é que por meio deles o Estado dá concretude aos direitos fundamentais sociais relacionados à ordem social.

Assim, a Previdência Social é a parte da Seguridade, sendo uma espécie de seguro público, que se difere do seguro privado pelo princípio da solidariedade (daí falar em Seguridade social - ou Segurança Social, como em Portugal - e não em seguro social). ${ }^{26}$ Seu objetivo é proteger o segurado nos momentos de incapacidade laboral, o que pode ocorrer por velhice, doença, acidentes, desemprego involuntário, morte etc. (HORVATH JÚNIOR, 2011, p. 1-2; JORGE, 2007, p. 11). Sua regulação está no art. 201 da Constituição, que prevê o Regime Geral de Previdência Social (RGPS).

A cobertura se dá mediante filiação obrigatória e é feita pelo pagamento de tributos chamados contribuições. Há diferentes tipos de contribuição, e sobre diferentes bases de cálculo. Por exemplo, há aquelas de titularidade da própria empresa, que incidem sobre o lucro (CSLL), sobre o (PIS/PASEP e COFINS) etc. Contudo, a proteção penal dos bens e valores da Seguridade Social está centralizada em uma forma especial de contribuição: a previdenciária sobre o salário do empregado.

Assim, é este tributo que, se descontado do salário e não recolhido, incide nas penas do art. 168-A, CP; ou que, se sonegado, incide nas penas do art. 337-A,

25 "Art. $6^{0}$ São direitos sociais a educação, a saúde, a alimentação, o trabalho, a moradia, o transporte, o lazer, a segurança, a previdência social, a proteção à maternidade e à infância, a assistência aos desamparados, na forma desta Constituição" "Art. 70, XXIV - aposentadoria".

26 Um dos marcos apontados para este modelo na doutrina é o relatório Beveridge, da década de 1940; cfr. Horvath Júnior (2011, p. 16 e 20). 
CP. Da mesma forma, o crime de falsificação de documento público atinge o empregador que faltar com a verdade quando da assinatura da CTPS de seu empregado (art. 297, §§ $3^{\circ}$ e $\S 40, \mathrm{CP}$ ).

Apesar das diferenças tributárias entre as contribuições em geral e a descontada do salário do empregado, ${ }^{27}$ deve-se ressaltar que tanto aquelas quanto esta são destinadas ao Orçamento da Seguridade Social da União, o que pode ser observado inclusive na discriminação das receitas das Lei Orçamentárias Anuais da União, como a LOA de 2020, lei n. 13.978/2020.

Portanto, todos esses tributos são federais e destinados à cobertura dos gastos da Seguridade Social, não havendo diferença substancial entre elas (BALTAZAR JÚNIOR, 2014, p. 117-118; ESTELLITA, 2001a, p. 215); até mesmo porque contribuições como a CSLL e a COFINS, p. ex., podem ser sonegadas e não-recolhidas, incidindo nas penas dos crimes da lei n. 8.137/90 (v. infra, 3.1).

\subsection{Os bens jurídico-penais da receita da Seguridade Social e da verdade} fiscal

Muito já se discutiu sobre a natureza dos bens jurídico-penais tutelados em âmbito dos crimes tributários. 0 problema é há muito debatido em países europeus, como Portugal, Espanha e Itália, tendo grande parte das contribuições desses países cruzado o Atlântico e influenciado fortemente a doutrina e a Jurisprudência nacionais.

Nestas linhas, não se deve realizar um estudo aprofundado sobre os principais marcos teóricos; não há espaço para tanto. Pode-se, contudo, ressaltar que, de um modo geral, há dois opostos formados por doutrinas que apostam, de um lado, no aspecto patrimonial do bem jurídico tutelado, enquanto que, do outro, em aspectos funcionais, como as funções dos tributos protegidos

27 É posição majoritária na doutrina e pacífica no STF a qualidade tributária das contribuições sociais, inclusive as descontadas do salário do empregado. Cfr. Carvalho (2009, p. 44-45); e Deligne; Matanzaz (2019, p. 687). Na Jurisprudência: BRASIL. Supremo Tribunal Federal. Recurso Extraordinário n. 560.626/RS. Relator: Min. Gilmar Mendes. Julgado em: 12 jun. 2008. 
jurídico-penalmente. Isto sem prejuízo de outros pontos de vista mais especializados. 28

No Brasil, o ponto majoritário é, com segurança, o que aposta no patrimônio da Fazenda Pública, como bem jurídico-penal supraindividual. ${ }^{29}$ Esta visão tem ampla inspiração na doutrina espanhola, e foi acatada pela Jurisprudência do Supremo Tribunal Federal, que, no julgamento do HC n. 76.978/RS, lê-se que se tutela a "[...] subsistência financeira da própria Previdência Social que 'a toda a sociedade', para relembrarmos o texto constitucional, fixa-se o dever de contribuir" (BRASIL, 1998).

Contudo, pensa-se que a hipótese mais adequada não é apenas a proteção patrimonial; menos ainda a proteção de um bem jurídico funcional, como determinadas funções de cada tributo. $O$ modelo adotado no presente trabalho é aquele que surge em doutrina portuguesa, com posterior aderência de alguma doutrina brasileira, que menciona dois bens jurídico-penais tutelados nos crimes tributários em geral: a receita e a verdade fiscal. ${ }^{30}$

Quanto à "receita", trata-se de delimitação mais concreta do que a simples menção ao patrimônio (SOUSA, 2006, p. 298); até mesmo porque a própria linguagem do direito financeiro nacional utiliza esse termo. ${ }^{31}$ No que tange à proteção da Seguridade Social, tutela-se uma receita que é de titularidade da União, cuja fonte é a contribuição previdenciária, e que compõe exclusivamente o Orçamento da Seguridade Social, o que está constitucionalmente disposto no art. 167, IX, CF, sendo vedada a utilização dessas verbas para qualquer fim outro que não a própria Seguridade Social.

28 Para um panorama geral, ver, no Brasil: Camargo; Silveira (2018, p. 9); Rodrigues (2013, p. 147); RUIVO (2019, p. 438); em Portugal: SOUSA (2006, p. 266); na Itália: LO MONTE (1996, p. 220); na Espanha: Torres Cadavid (2007, p. 52); e, colocando as funções dos tributos como bens jurídico-penais, v. Gracia Martín (1994, p. 194).

29 Por todos, v. Bitencourt (2016, p. 761), para quem o art. 168-A tutela a "legítima expectativa de ingressos ao erário público"; já nos crimes de sonegação (arts. 10, lei n. 8.137/90 e 337-A, CP), o bem jurídico é "o patrimônio administrado pela Fazenda Pública na sua faceta de ingressos e gastos públicos", adicionando que não se trata do patrimônio já formado, mas à "legítima expectativa de ingressos ao Tesouro Público" (grifo do autor, p. 723).

30 Dias; Andrade (1996, p. 58 e 63); Fernandes (2006, p. 1133-1135). No Brasil: D’avila; Bach (2018, p. 277 e 279$)$ e Ruivo (2019, p. 441 e 444).

31 Chimenti (2018, p. 241) destaca que, nas ciências contábeis, a receita é formada pelo ingresso definitivo de recursos ou bens no patrimônio público, enquanto, para a legislação (v. lei $n$. $4.320 / 61$, art. $11, \S \S 1^{\circ}$ a $4^{\circ}$ ) não se exige que 0 ingresso de receitas acresça o patrimônio público. 
Nesse sentido, fica evidente que todos os delitos que visam proteger a arrecadação da Seguridade Social, através do bem jurídico, "receita da Seguridade Social", estão protegendo um bem específico e delimitado pelo próprio orçamento público. Portanto, é incorreto falar apenas em crimes previdenciários; esta denominação, bem como a de direito penal previdenciário, é correta apenas no que diz respeito à dinâmica desses tributos, até mesmo porque o sistema de Seguridade Social só existe no Brasil desde 1988. Evidentemente, a arrecadação de exações como o ICMS ou o IPI possui uma dinâmica completamente diferente à das contribuições sociais. Estas têm disposições muito próprias, inclusive pelo próprio Regimento da Previdência Social (Decreto n. 3.048-99) que prevê, p. ex., a forma de declaração dessa espécie tributária, bem como sanções administrativas para determinadas condutas. ${ }^{32}$

Portanto, pode-se falar em um direito penal previdenciário, sem jamais desvelar-se de que os crimes em questão visam proteger o Sistema de Seguridade Social, através de sua receita e da verdade de suas informações, que correspondem, na prática do dia-a-dia, ao setor do direito previdenciário, pela natureza do tributo, os sujeitos tributários, a forma de declaração etc.

Ademais, quanto ao bem jurídico da verdade fiscal, também são necessárias delimitações, até mesmo porque eventualmente fala-se também em "transparência". $\mathrm{Na}$ doutrina estrangeira, encontra-se quem defenda uma visão funcionalista da verdade, como na Itália, a transparenza fiscale (LO MONTE, 1996, p. 220) ou a mais recente tutela instrumental da "atividade de fiscalização" (SALCUNI, 2001, p. 135, traduziu-se; na jurisprudência: ITÁLIA, 2013), concretizado nas declarações fiscais do contribuinte. No Brasil, Lovatto (2003, p. 88) defende o bem jurídico "ordem tributária", cuja existência depende da veracidade de declarações, documentações, lançamentos etc., havendo uma proteção penal da verdade.

A proposta ora trabalhada não corresponde necessariamente às acima mencionadas, mas é importante destacar que a proteção penal da verdade não é incidental, tampouco uma hipótese recente. $\mathrm{O}$ que se pretende proteger com a tutela

32 Por exemplo: "Art. 242, § $1^{\circ}$ Os valores das contribuições incluídos na Guia de Recolhimento do Fundo de Garantia do Tempo de Serviço e Informações à Previdência Social, não recolhidos ou não parcelados, serão inscritos na Dívida Ativa do Instituto Nacional do Seguro Social, dispensando-se o processo administrativo de natureza contenciosa". 
da verdade fiscal é a proteção do livre trânsito de informações no sistema cuja lesão ocorre com a fraude, já que "a razão de ser da fraude é fazer que o falso aparente ser verdadeiro", ${ }^{\prime 3}$ o que se observa nos crimes fiscais em que o contribuinte ou substituto simula situação não verdadeira para obter algum tipo de vantagem econômica.

Ademais, veja-se que as outras figuras anteriormente citadas, igualmente ofensivas à Seguridade Social, também visam proteger os bens jurídicos ora propostos, desde que praticados em seu detrimento. 0 crime de estelionato contra entidade de direito público (art. 171, § 30, CP), em que o sujeito obtém, junto ao INSS, benefício a que não tem direito mediante fraude, trata de uma modalidade de enriquecimento ilícito às custas da receita da Seguridade Social; da mesma forma, a fraude perpetrada ataca a verdade fiscal. Nesse tipo de caso, haverá crime

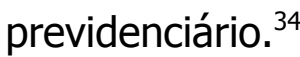

Quanto ao crime de falsidade do art. 297 , $\S \S 3^{\circ}$ e $4^{\circ}$, trata-se de crime de falsidade, que visa proteger a verdade fiscal no âmbito do sistema de Seguridade Social, sem prejuízo de falar-se em uma proteção ao trabalhador, desde que por via lateral (PAULSEN, 2017, p. 378).

Os crimes informáticos dos arts. 313-A e 313-B, CP, por sua vez, também tutelam a verdade fiscal no que tange à higidez dos sistemas informáticos da Previdência, havendo também uma tutela da receita no caso do primeiro crime, que, como visto, é praticado pelo funcionário público para enriquecimento ilícito assim como o estelionato previdenciário é praticado pelo particular.

\section{HÁ UMA AUTONOMIA PARA O DIREITO PENAL DA SEGURIDADE SOCIAL?}

O direito penal da Seguridade Social se apresenta, assim, como um tipo complexo de criminalidade, cuja proteção penal visa a preservação de dois bens

33 Ruivo (2019, p. 442-443), menciona como valor nuclear deste bem o "dever de prestação de informações imposto ao contribuinte pelo Estado, que recebe tutela penal específica pelos crimes de falsificação de documento particular (art. 297, do CP), falsificação de documento público (art. 298, do CP) e falsidade ideológica (art. 299, do CP)".

34 Há inúmeras possibilidades de falsificação de documentos destinada à obtenção do benefício indevido, como a pessoa que obtém pensão por morte fingindo ser ex-companheiro(a) de segurado(a) falecido(a); v. Paulsen (2017, p. 193). 
jurídicos, ora conjuntamente, ora individualmente. Nesse sentido, não é correto limitar o alcance dos crimes previdenciários apenas aos seus crimes tributários, tendo em vista que há uma gama de outros crimes que também tutelam a Seguridade Social, mas que não possuem a dinâmica dos crimes tributários, como os crimes previdenciários informáticos ou de falsidade.

Nesse sentido, os crimes contra a Seguridade Social não integram exclusivamente a disciplina do direito penal econômico, tampouco exclusivamente o direito penal clássico. A complexidade desses fenômenos apenas demonstra o cuidado que se deve ter ao especializar demais determinada área do conhecimento. ${ }^{35}$ Ademais, veja-se que o direito penal tradicional também tutela bens jurídicos supraindividuais, basta ver o caso do estelionato previdenciário.

Nesse sentido, fica evidente a resposta à pergunta que batiza o presente título: o direito penal da Seguridade Social não constitui disciplina autônoma, tampouco se encaixa apenas na criminalidade "econômica" ou "clássica". Ora, não é toda e qualquer particularidade de um determinado fenômeno criminal que incorrerá em particulares ou diferentes objeto, método e princípios. Se se assume que o direito penal econômico, em sua realidade fragmentada, possui singularidades que não são abarcadas pelo direito penal tradicional, não se pode admitir a mesma sorte para cada segmento deste último ( $\mathrm{v} . \mathrm{g}$. crimes contra o mercado de capitais, contra as relações de consumo etc.) (COSTA, 2003, p. 23).

O que importa destacar é aquilo que já se firmou: o fundamento do direito penal, seja tradicional, seja econômico, é a exclusiva proteção de bens jurídico-penais. Se determinado tipo de criminalidade ofende, portanto, os bens jurídicos da Seguridade Social, está-se diante de crimes contra a Seguridade Social. Isto não incorre falar em uma disciplina autônoma, senão um segmento do direito penal Econômico.

35 COSTA (2003, p. 23) adverte que "a especialização, quando mal compreendida, é, de modo insofismável, o lugar privilegiado, por antonomásia, de equívocos", recusando, p. ex., um "direito penal do consumidor" pelo simples fato de haver crimes contra as relações de consumo. Se fosse assim, toda e qualquer criminalidade da parte especial do código penal teria uma disciplina própria: haveria um Direito Penal da Vida, um Direito Penal das relações de trabalho etc. É claro que todos esses ramos possuem características próprias e que devem ser assim analisadas; isto, contudo, não os coloca como novas disciplinas, ou como ciências autônomas. 


\subsection{Pode haver tratamento diferente entre os crimes contra a seguridade social e tributários?}

Uma última questão que se deve abordar é o tratamento que o legislador e os Tribunais dão aos crimes previdenciários, quando comparados aos demais crimes contra a ordem tributária em geral. Como visto acima, não há uma diferença substancial entre a proteção penal da Seguridade Social e a de outros ramos do direito penal (econômico ou tradicional), o grande diferencial são os bens jurídicos que se visam proteger.

Os crimes tributários em geral, disciplinados na lei n. 8.137/90 (além dos arts. 334 e 334-A do CP, descaminho e contrabando, que não serão aqui analisados), também protegem os bens jurídico-penais da receita e da verdade fiscal, com a diferença da receita ser aquela fiscal (e não da Seguridade Social) e de o sistema tributário ser outro, mas que igualmente preza pela verdade do trânsito de suas informações. ${ }^{36}$

Contudo, seguidamente nega-se isonomia aos crimes previdenciários e tributários. Veja-se os casos a seguir.

\subsubsection{A diferença de penas entre os arts. 20, II, lei n. 8.137/90 e 168-A, CP}

Talvez o caso mais notório se dê na comparação entre duas figuras típicas. Tratam-se de duas condutas idênticas, mas cujas penas diferem muito em sua quantificação. Isto porque a pena do crime de não-recolhimento de tributo, que visa a proteção dos bens jurídicos da ordem tributária em geral, é apenado com detenção de 6 meses a 2 anos; $; 7$ enquanto que a pena do crime de não-recolhimento de contribuições previdenciárias prevê pena de reclusão de 2 a 5 anos. ${ }^{38}$

36 D'avila; Bach (2018, p. 279); Ruivo (2019, p. 442).

37 "Art. $1^{\circ}$ Constitui crime contra a ordem tributária suprimir ou reduzir tributo, ou contribuição social e qualquer acessório, mediante as seguintes condutas: [...]. Art. $2^{\circ}$ Constitui crime da mesma natureza: [...] II - deixar de recolher, no prazo legal, valor de tributo ou de contribuição social, descontado ou cobrado, na qualidade de sujeito passivo de obrigação e que deveria recolher aos cofres públicos; [...]. Pena - detenção, de 6 (seis) meses a 2 (dois) anos, e multa".

38 "Art. 168-A. Deixar de repassar à previdência social as contribuições recolhidas dos contribuintes, no prazo e forma legal ou convencional: pena - reclusão, de 2 (dois) a 5 (cinco) anos, e multa. § $1^{0}$ Nas mesmas penas incorre quem deixar de: I - recolher, no prazo legal, contribuição ou outra 
Na doutrina, encontra-se eventual justificativa do apenamento mais gravoso para o crime previdenciário pelo fato de as contribuições previdenciárias estarem destinadas ao Orçamento da Seguridade Social, não podendo ser desviada de sua destinação.

Este argumento, contudo, não é suficiente para justificar essa diferença. Como ressaltado por grande parte da doutrina, os outros tributos federais também podem ser destinados aos gastos da Seguridade Social; o Orçamento Fiscal da União seguidamente complementa as despesas do Orçamento da Seguridade Social. ${ }^{39}$

Além disso, seria temerário dizer que as despesas da Seguridade Social são mais valiosas para o Estado do que as dos demais tributos. E os gastos destinados à educação e à saúde, por exemplo? Evidentemente, trata-se de prestações de direitos fundamentais, também alinhadas com os objetivos de construir uma sociedade livre, justa e igualitária, e de promover o bem de todos. Não é justa, portanto, essa discriminação.

Enfim, resta claro que não há justificativa plausível para uma diferença de penas tal como na realidade se apresenta. Há, aqui, uma violação ao princípio da proporcionalidade (em sentido estrito) e da isonomia, por negar tratamento igual a situações iguais.

\subsubsection{A igualdade de penas entre os arts. 168-A e 337-A, CP}

Na escorreita do problema anterior, surge outro quase idêntico. Desta vez, deve-se reparar que o apenamento do crime de não-recolhimento de contribuição é, rigidamente, idêntico ao de sonegação de contribuição previdenciária: ${ }^{40}$ ambos

importância destinada à previdência social que tenha sido descontada de pagamento efetuado a segurados, a terceiros ou arrecadada do público".

39 V. Baltazar Júnior (2014, p. 117-118 e 155); Estellita (2001, p. 101); Estellita (2001a, p. 216); Maciel Filho (2004, p. 214); Stoco, R.; Stoco, T. (2016, p. 114).

40 "Art. 337-A. Suprimir ou reduzir contribuição social previdenciária e qualquer acessório, mediante as seguintes condutas: I - omitir de folha de pagamento da empresa ou de documento de informações previsto pela legislação previdenciária segurados empregado, empresário, trabalhador avulso ou trabalhador autônomo ou a este equiparado que lhe prestem serviços; II - deixar de lançar mensalmente nos títulos próprios da contabilidade da empresa as quantias descontadas dos segurados ou as devidas pelo empregador ou pelo tomador de serviços; III - omitir total ou parcialmente, receitas ou lucros auferidos, remunerações pagas ou creditadas e demais fatos geradores de contribuições sociais previdenciárias: Pena - reclusão, de 2 (dois) a 5 (cinco) anos, e multa". 
preveem reclusão de 2 a 5 anos. A questão é que o crime de sonegação é, reconhecidamente, um crime de fraude, elemento este que é inexistente no crime de não-recolhimento.

Pode haver igualdade de penas para condutas desigualmente gravosas? Não é preciso nem buscar a dogmática penal, trata-se de um problema de lógica: a resposta é não! $E$, consultando-se a dogmática, não se chega a outra conclusão. ${ }^{41}$ Há, também aqui, um problema de proporcionalidade em sentido estrito e também de igualdade, uma vez que se protege, com igual gravidade, diferentes graus de ofensa a bens jurídico-penais. ${ }^{42}$

Aliás, fica em aberta a questão se o art. 168-A, CP, protege realmente o bem jurídico da verdade fiscal, tendo em vista que a agressão a este bem é, tradicionalmente, realizada mediante a fraude, que inexiste no tipo em questão.

O STF não se pronunciou diretamente sobre o tema, mas pronunciou-se sobre a extinção de punibilidade prevista para ambos os crimes, no julgamento da ADI n. 4.974. No voto da relatora, ministra Rosa Weber, lê-se que o crime de sonegação é mais grave que o de não-recolhimento, e que por esse motivo, deve ser mais criteriosa a extinção de sua punibilidade pelo pagamento. ${ }^{43-44}$ Sem entrar no

41 "[...] evidente que a falsidade ou a fraude são largamente mais ofensivas à consciência jurídica que a mera omissão no recolhimento de tributo declarado, ainda que descontado de terceiro" (BALTAZAR JÚNIOR, 2014, p. 155); v. também Lemes (2009, p. 104); Estellita, 2001a, p. 215).

42 V. Ruivo (2018, p. 593 e 609), que faz a comparação entre o aumento de pena nos crimes de furto e de lesões corporais, ambos causados pelo concurso de pessoas. Esses crimes protegem, respectivamente, a o patrimônio e a incolumidade física; mesmo assim, no crime patrimonial há uma qualificadora, enquanto que, no outro, uma majorante, o que é ilógico e dogmaticamente injustificado.

43 Ao julgar-se o $\S 1^{\circ}$ do art. 337-A, CP, decidiu-se que não se viola o princípio da proporcionalidade, por se tutelar suficientemente o bem jurídico do patrimônio da Previdência; ademais, v.: "Da leitura da tipificação dos dois crimes, percebe-se que, como requisito para a extinção da punibilidade do agente da apropriação indébita previdenciária, diferentemente do quanto disposto no que atine à sonegação de contribuição previdenciária, exige-se, além das espontâneas declaração, confissão e prestação das informações, seja efetuado o pagamento das contribuições, importâncias ou valores. Embora ambos os tipos proscrevam condutas voltadas à evasão tributária e à lesão ao patrimônio público, a distinção de tratamento jurídico é justificada pelo fato de, no crime de apropriação indébita previdenciária, o agente já dispor dos valores que recolheu dos contribuintes e, indevidamente, deixou de repassar aos cofres da Previdência Social. Proporcional, portanto, uma vez adequada, necessária e, mormente porque atendida proporção entre meio e fim (proporcionalidade em sentido estrito), a diferença legislativa no tratamento da extinção da punibilidade entre os dois crimes - e, por consequência, entre os demais tipos penais elencados pelo requerente" (BRASIL, 2019, p. 14).

44 Registre-se que a Corte Constitucional italiana julgou caso relativamente semelhante. $O$ objeto do julgamento eram os crimes fiscais previstos no D. Lgs. n. 74/2000; respectivamente, os crimes de: omesso versamento di IVA (art. 10-ter); omessa dichiarazione (art. 5) e dichiarazione infidele (art. 
mérito dessa questão, percebe-se que o Tribunal julgou haver diferença de gravidade entre ambos, sem, contudo, apreciar a curiosa igualdade das penas.

\subsubsection{O princípio da insignificância e o art. 168-A, CP}

Por derradeiro, há o problema da não aplicação do princípio da insignificância nos crimes tributários contra a Seguridade Social, tomando-se novamente por exemplo o crime do art. 168-A, CP.

Sabe-se que a questão da insignificância se insere no contexto da tipicidade penal; isto é, não basta haver um tipo formal, um tipo de lei que incrimine determinada conduta de agir ou deixar de agir: é necessária a tipicidade material (BALTAZAR JÚNIOR, 2014, p. 133-134). E, neste particular, há uma diversidade muito grande de hipóteses sobre o conceito material de crime, ou mesmo sobre a aplicação do princípio da insignificância e suas relações com o tipo penal.

No presente estudo, porém, já se optou por um conceito de crime enquanto ofensa a bens jurídico-penais; e, nesse sentido, haverá tipicidade material se houver ofensa aos bens jurídicos em questão. Em outras palavras: mesmo havendo um não-recolhimento de tributo, devido ao seu baixo montante, pode-se incidir a não relevância penal da conduta, pois, embora formalmente típica, não há ofensa ao bem jurídico, i.e., não há tipicidade material.

Nesse sentido, discute-se sobre qual seria o mínimo valor para falar-se em tipo material, no caso dos crimes tributários, falando alguns em $R \$ 10.000,00$, nos

4). Desses três crimes, apenas o primeiro é cometido sem fraude; os outros dois requerem meios fraudulentos para evasão fiscal, possuindo penas maiores. No entanto, havia uma diferença na soglia di punibilità, i.e., o limite mínimo de valor sonegado em euros - assim, o crime não-fraudulento exigia uma quantia menor que os fraudulentos. A Corte, nesse sentido, julgou que: "A lesão ao princípio da igualdade inerente a um tal regime se manifesta no fato de que a omissão de declaração e a declaração infiel constituem ilícitos incontestavelmente mais graves, sobre o plano da atitude lesiva aos interesses do fisco, do que o não-recolhimento do IVA: e isto, na mesma consideração do legislador, como emerge do confronto das respectivas penas editadas (reclusão de um a três anos, para os primeiros dois crimes; de seis meses a dois anos, para o terceiro)" (ITÁLIA, 2014, tradução nossa). A questão é diferente, pois não trata da pena, mas da punibilidade. Mesmo assim, há um evidente problema de desigualdade, o que foi reconhecido pela Corte, utilizando-se como medida também a diferença de penas entre os delitos. Sobre a questão da punibilidade esta categoria é discutida em doutrina europeia como se integrante ou não do modelo analítico de crime (tipo, ilícito e culpa), havendo particular preocupação na doutrina italiana. Assim, em crimes tributários, v. Aires de Sousa (2006, p. 301); Zecca (2016, p. 235); em doutrina geral do crime: v. Dolcini; MarinuccI (1999, p. 476). 
termos da lei n. 11.457/07; outros, em R\$20.000,00, nos termos da lei n. 10.522/07 e da Portaria n. 75/2012 do então Ministério da Fazenda. A Jurisprudência do STJ já acatou a primeira hipótese de insignificância; ${ }^{45}$ enquanto alguns Tribunais Regionais Federais, a segunda. ${ }^{46}$

A questão que ora se coloca não é o valor da insignificância. O problema é quando há o afastamento dessa possibilidade pela natureza do bem jurídico-penal tutelado; isto é, quando se decide que, em se tratando da receita da Seguridade Social, não cabe esta aplicação.

Esta negação foi pronunciada pelo STF, em julgamento de Habeas Corpus no qual o agente teria não recolhido o valor de $\mathrm{R} \$ 2.020,00$. No voto do relator, ministro Ricardo Lewandowski, lê-se que o não-recolhimento de contribuições previdenciárias é conduta "qualificada por um intenso grau de reprovabilidade" (BRASIL, 2010, p. 523), uma vez que "o bem jurídico tutelado pela norma penal é a 'subsistência financeira da Previdência Social'" (BRASIL, 2010, p. 523). Nesse sentido, a conduta do paciente "além de descumprir um dever que tem para com a Previdência Social, violou também o direito de toda a sociedade de ter um sistema previdenciário que goze de saúde financeira, apto a garantir a todos a cobertura naquelas situações de necessidade" (BRASIL, 2010, p. 524).

O ministro relator ainda mencionou "a situação deficitária em que se encontra a Previdência Social, consoante atesta relatório do Tribunal de Contas da União sobre as contas do Governo da República referente ao exercício de 2009 [...]" (BRASIL, 2010, p. 526). Assim, concluiu o votante pela denegação da ordem, "dado o caráter supraindividual do bem jurídico tutelado pela norma - o patrimônio da Previdência Social [...] aliado à circunstância de a conduta do paciente contribuir

45 "Caso em que é pertinente a tese sufragada pelo Recorrente quanto à inaplicabilidade, na espécie, do princípio da insignificância, considerando que o valor do débito previdenciário apropriado pela Recorrida, no montante de $\mathrm{R} \$ 3.899,55$ (três mil oitocentos e noventa e nove reais e cinqüenta (sic) e cinco centavos), é superior aquele equivalente ao previsto no artigo 10 da Lei n. 9.441/97 e na Portaria n. 4.910/99 do Ministério da Previdência e Assistência Social, que consolidou a extinção do crédito para valores iguais ou inferiores a R\$1.000,00 [sic]" (BRASIL, 2013).

46 "Aplicação do princípio da insignificância. O valor da contribuição previdenciária não recolhida, afastados juros de mora e multa, é inferior àquele previsto como o valor mínimo executável ou que permite o arquivamento, sem baixa na distribuição, das execuções fiscais de débitos inscritos como Dívida Ativa da União, nos termos do artigo 20 da Lei n. 10.522/2002 e da na Portaria no 75/2012 do Ministério da Fazenda, a qual elevou o referido montante para R\$20.000,00 (vinte mil reais)" (BRASIL, 2013a). 
para agravar o quadro da já combalida da previdência social brasileira" (BRASIL, 2010, p. 527-528).

Tomando em consideração o que foi anotado nestas breves linhas, não é possível concordar com a conclusão a que chegou o Supremo Tribunal Federal. Inicialmente, é de se anotar que o verdadeiro grau de reprovabilidade de uma conduta se dá na medida da ofensividade ao bem jurídico-penal tutelado; configurando-se, assim, a tipicidade objetiva no caso concreto ou não.

Ademais, a situação atuarial da Previdência Social é totalmente indiferente à conduta do agente. Ora, não é ao empresário (substituto tributário) que a Constituição atribui o dever de equilíbrio financeiro e atuarial, mas ao Poder Público, em suas esferas competentes para tanto. ${ }^{47}$ Se este, por sua vez, não conseguiu impedir uma situação de desequilíbrio, não pode este fator ser invocado na imputação do agente que, formalmente, perpetrou a conduta penalmente proibida pelo art. 168-A, CP.

Por fim, a supraindividualidade do bem jurídico-penal, como visto, não é particularidade dos bens da Seguridade Social; pelo contrário, uma série de crimes abarcados pelo direito penal econômico tutela bens supraindividuais, e mesmo o direito penal clássico o faz. Do mesmo modo, os crimes tributários de um modo geral também lidam com bens com essas mesmas características, sem contar que os demais tributos também podem ser destinados ao custeio da Seguridade Social.

Nesse sentido, conclui-se que não é possível atribuir aos crimes contra a Seguridade Social tratamento diverso daquele dado aos crimes tributários em geral.

\section{CONCLUSÃO}

1. O direito penal econômico constitui disciplina autônoma, possuindo objeto, método e princípios próprios, e que se encontra ligado ao direito penal tradicional, constituindo com ele uma unidade. Além disso, ele tutela bens jurídicos supraindividuais, cujo fundamento se encontra na pessoa humana. Um de seus

\footnotetext{
47 "Art. 195, § 50 Nenhum benefício ou serviço da seguridade social poderá ser criado, majorado ou estendido sem a correspondente fonte de custeio total".
} 
ramos é o direito penal tributário, onde se localizam os principais crimes contra a Seguridade Social (arts. 168-A e 337-A, ambos do CP).

2. Pode-se falar tanto em direito penal da Seguridade Social quanto em direito penal previdenciário, desde que em contextos bem delimitados.

2.1 Nesse sentido, deve-se diferenciar Seguridade Social e Previdência Social: este último é um dos pilares daquele, sendo mais restrito no que tange aos seus benefícios, que visam a cobertura do indivíduo que estiver provisória ou definitivamente desprovido de sua capacidade laboral (ex. velhice, doença, desemprego etc.).

2.2 A terminologia mais correta é "direito penal da Seguridade Social", pois é ela a titular dos bens jurídico-penais atingidos por esse tipo de criminalidade: a receita e a verdade fiscal. Contudo, pode-se falar em direito penal previdenciário, desde que em contextos limitados pela dinâmica de recolhimento dos tributos ligados estritamente ao ramo da Previdência Social, como a contribuição previdenciária que é o objeto material dos crimes tributários de não-recolhimento de contribuições previdenciárias (art. 168-A, CP) e sonegação de contribuições previdenciárias (art. 337-A, CP).

2.3 Os demais crimes praticados em âmbito previdenciário, como o de estelionato previdenciário (art. 171, $3^{\circ} \mathrm{CP}$ ) e a falsificação na CTPS (art. 297, § $3^{\circ} \mathrm{e}$ incisos) possuem maior abrangência, e podem ser cometidos contra outras entidades estatais ou em contextos específicos das relações de trabalho (v. CTPS), de modo que o prejuízo da Seguridade Social ou da Previdência é apenas incidental. Logo, pode-se mencioná-los como crimes contra a Seguridade Social, mas essa delimitação é incidental; tampouco se pode associá-los, necessariamente, à disciplina do direito penal econômico, pois essas figuras são antigas e analisadas desde o direito penal tradicional.

3. Não se pode falar em uma disciplina do direito penal da Seguridade Social, sendo este um seguimento do direito penal econômico, no que tange aos crimes tributários. Por esse motivo, não deve haver uma diferença de tratamento entre esses crimes e os demais crimes tributários; a Jurisprudência do STF, nesse sentido, é oscilante. 


\section{REFERÊNCIAS}

BALTAZAR JÚNIOR, José Paulo. Crimes federais. 9. ed. rev. e ampl. São Paulo: Saraiva, 2014.

BITENCOURT, Cezar Roberto. Tratado de direito penal 4: crimes contra a dignidade sexual até crimes contra a fé pública. São Paulo: Saraiva, 2020.

BITENCOURT, Cezar Roberto. Tratado de direito penal econômico. São Paulo: Saraiva, 2016.

BRASIL. Superior Tribunal de Justiça. Agravo Regimental no Recurso Especial n. 1.389.169/MG. Penal e processo penal. Agravo regimental no recurso especial. Contrariedade ao art. 168-A do CP. Apropriação indébita previdenciária. Resp repetitivo $n^{0} 1.112 .{ }^{748} /$ to. Débito não superior a $R \$ 10.000,00$ (dez mil reais). Princípio da insignificância. Aplicação. Dívida ativa da União. Lei $11.457 /{ }_{07}$. Acórdão em conformidade com a Jurisprudência desta corte. Súmula ${ }^{88 / S T J}$. Agravo regimental a que se nega provimento. Relatora: Min. Maria Thereza de Assis Moura, 24 de outubro de 2013. Disponível em:

https://stj.jusbrasil.com.br/jurisprudencia/24658436/agravo-regimental-no-recurso-e special-agrg-no-resp-1389169-mg-2013-0204134-4-stj. Acesso em: 07 out. 2021

BRASIL. Supremo Tribunal Federal. Ação Direta de Inconstitucionalidade n. 4.974/DF. Ementa. Constitucional. Controle de constitucionalidade. Alegação de inconstitucionalidade material do artigo 337-A, caput, do Código Penal - crime de sonegação de contribuição previdenciária -, por violação dos artigos 30; 50, caput e inciso I; 194, caput e inciso V; E 195 da constituição Federal, bem como do princípio da proporcionalidade. Improcedência. Relatora: Min. Rosa Weber, 18 de outubro de 2019. Disponível

em: https://stf.jusbrasil.com.br/jurisprudencia/861996417/acao-direta-de-inconstitucionali dade-adi-4974-df-distrito-federal-9989374-0320131000000. Acesso em: 08 out. 2021.

BRASIL. Supremo Tribunal Federal. Habeas Corpus n. 76.978/RS. Habeas-corpus. Crime contra a ordem tributária praticado em continuidade delitiva: não recolhimento de contribuição previdenciária descontada de empregados. Alegações de: exclusão da ilicitude por inexistência de dolo; extinção da punibilidade pelo parcelamento do débito; inexistência de mora por vício na notificação administrativa, porque dirigida à pessoa jurídica; atipicidade do crime de apropriação indébita; e de aplicação da lex gravior em detrimento da lex mitior: ultra-atividade da lei penal quando, após o início de crime continuado, sobrevem lei mais severa. Relator: Min. Maurício Corrêa, 29 de setembro de 1998. Disponível em:

https://redir.stf.jus.br/paginadorpub/paginador.jsp?docTP=AC\&docID=77011. Acesso em: 08 out. 2021. 
BRASIL. Supremo Tribunal Federal. Habeas Corpus n. 98.021/SC. Penal. Habeas Corpus. Art. 168-A do Código Penal. Apropriação indébita previdenciária. Bem jurídico tutelado. Patrimônio da Previdência Social. Caráter supraindividual. Princípio da insignificância. Inaplicabilidade. Reprovabilidade do comportamento. Ordem Denegada. Relator: Min. Ricardo Lewandowski, 22 jun. 2010. Disponível em: https://stf.jusbrasil.com.br/jurisprudencia/15667876/habeas-corpus-hc-98021-sc/intei ro-teor-103284958. Acesso em: 08 out. 2021.

BRASIL. Supremo Tribunal Federal. Recurso Extraordinário n. 560.626/RS. Prescrição e decadência tributárias. Matérias reservadas a lei complementar. Disciplina no código tributário nacional. Natureza tributária das contribuições para a seguridade social. Inconstitucionalidade dos arts. 45 e 46 da lei 8.212/91 e do parágrafo único do art. $5^{\circ}$ do decreto-lei $1.569 / 77$. Recurso extraordinário não provido. Modulação dos efeitos da declaração de inconstitucionalidade. Relator: Min. Gilmar Mendes, 12 de junho 2008. Disponível em:

https://redir.stf.jus.br/paginadorpub/paginador.jsp?docTP=AC\&docID=567931. Acesso em: 08 out. 2021.

BRASIL. Tribunal Regional Federal da $4^{a}$ Região. Apelação Criminal n. 5004397-05.2014.4.04.7008. Relator: Des. Carlos Eduardo Thompson Flores Lenz, 03 de março de 2021.

BRASIL. Tribunal Federal Regional da $4^{a}$ Região. Apelação Criminal n. 0001805-16.2001.4.03.6181. Relator: des. Vesna Kolmar, 09 de abril de 2013.

CAMARGO, Beatriz Corrêa; SILVEIRA, Renato de Mello Jorge. Autodenúncia ao invés de pagamento do tributo como condição para extinção da punibilidade nos crimes tributários. Análise a partir do bem jurídico protegido. Jornal de Ciências Criminais, São Paulo, v. 1, n. 1, p. 7-22, jul./dez. 2018.

CARVALHO, Paulo de Barros. Curso de direito tributário. 21. ed. São Paulo: Saraiva, 2009.

CHIMENTI, Ricardo Cunha. Direito tributário: direito financeiro, direito orçamentário e lei de responsabilidade fiscal. 20. ed. São Paulo: Saraiva, 2018.

COSTA, José de Faria. Direito penal económico. Coimbra: Quarteto, 2003.

D'AVILA, Fabio Roberto; BACH, Marion. O ilícito-típico de sonegação. Incompreensões sobre o ilícito penal em âmbito tributário. In: ADAMY, Pedro Augustin; FERREIRA NETO, Arthur M. (org.). Tributação do Ilícito: estudos em comemoração aos 25 anos do Instituto de Estudos Tributários - IET. São Paulo: Malheiros. 2018, p. 265-286.

DELIGNE, Maysa de Sá Pittondo; MATANZAZ, Sara Carvalho. Da tipificação dos crimes previdenciários: Compatibilidade e proporcionalidade prática. In: RUIVO, Marcelo Almeida; BOSSA, Gisele Barra (org..). Crimes contra ordem tributária: do direito tributário ao direito penal. São Paulo: Almedina, 2019, p. 681-706. 
DIAS, Jorge de Figueiredo. Para uma dogmática do direito penal secundário. Um contributo para a reforma do direito penal económico e social português. In: PODVAL, Roberto (org.). Temas de direito penal econômico. São Paulo: Revista dos Tribunais, 2000, p. 11-63.

DIAS, Jorge de Figueiredo; ANDRADE, Manuel da Costa. O crime de fraude fiscal no novo direito penal tributário português (considerações sobre a factualidade típica e o concurso de infracções). Revista brasileira de Ciências Criminais, ano 4, v. 13. São Paulo: Revista dos tribunais, 1996, p. 54-78.

DOLCINI, Emilio; MARINUCCI, Giorgio. Corso di diritto penale 1: le fonti, il reato: nozione, struttura e sistemática. 2. ed. Milano: Giuffrè, 1999.

DOLCINI, Emilio; MARINUCCI, Giorgio. Costituzione e politica dei beni giuridici. Rivista italiana di diritto e procedura penale, v. 37, p. 333-373, 1994.

ESTELLITA, Heloisa. O princípio constitucional da isonomia e o crime de omissão no recolhimento de contribuições previdenciárias (art. 168-A, § 10 I, Código Penal). In: ESTELLITA, Heloisa (coord.). Direito penal empresarial. São Paulo: Dialética, 2001, p. 95-105.

ESTELLITA, Heloisa. A tutela penal e as obrigações tributárias na constituição federal. São Paulo: Revista dos Tribunais, 2001a.

FELDENS, Luciano. A constituição penal: a dupla face da proporcionalidade no controle de normas penais. Porto Alegre: Livraria do advogado, 2005.

FERNANDES, Petra Monteiro. Breves considerações sobre o crime de abuso de confiança em relação à segurança social e o seu paradigma na legislação brasileira o crime de apropriação indébita previdenciária. In: COSTA, José de Faria; SILVA, Marco Antonio Marques da (coord.). Direito Penal Especial, Processo Penal e Direitos Fundamentais - visão Luso-Brasileira. São Paulo: Quartier Latin, p. 1126-1147, 2006.

FIANDACA, Giovanni. Il bene giuridico come problema teorico e come criterio di politica criminale. Rivista italiana di diritto e procedura penale, v. 25, p. 42-81, 1982.

FRAGOSO, Heleno Cláudio. Novo direito penal tributário e econômico. A Justiça Penal e a Revolução. Rio de Janeiro, 1965, p. 1-24. Disponível em: https://bit.ly/3dUx0qS. Acesso em: 25 fev. 2021.

GOMES, Luiz Flávio; BORSIO, Marcelo Fernando. Crimes previdenciários. 2. ed. rev. atual. e ampl. São Paulo: Revista dos Tribunais, 2014. 
GRACIA MARTÍN, Luis. Nuevas perspectivas del derecho penal tributario: las funciones del tributo como bien jurídico. Actualidad penal, Madrid, v. 1, n. 1/26, p. 183-217, 1994.

HOLMES, Stephen; SUNSTEIN, Cass R. The cost of rights: why liberty depends on taxes. New York; London: W. W. Norton \& Company, 1999.

HORVATH JÚNIOR, Miguel. Direito previdenciário. Barueri: Manole, 2011.

HUNGRIA, Nelson. Comentários ao Código Penal (Decreto-Lei n. 2.848, de 7 de dezembro de 1940): v. VII, arts. 155 a 196. 2. ed. rev. e atual. Rio de Janeiro: Forense, 1958.

ITÁLIA. Corte Costituzionale. Sentenza n. 80. Reati e pene - Omesso versamento dell'IVA - Fatti commessi sino al 17 settembre 2011 - Trattamento deteriore per il contribuente che dopo aver presentato la dichiarazione omette di versare l'imposta da lui stesso autoliquidata, rispetto al contribuente che, al fine di evadere I'IVA, presenta una dichiarazione infedele o non presenta affatto la dichiarazione - Omessa descrizione della fattispecie a quo - Manifesta inammissibilità del la questione. Relatore: Giuseppe Frigo, 07 de abril de 2014. Disponível em:

https://www.cortecostituzionale. it/actionSchedaPronuncia.do?anno=2014\&numero=8 0. Acesso em: 08 out. 2021.

ITÁLIA. Corte Suprema di Cassazione. Sentenza n. 37424. Relatore: Arturo Cortese, 28 de março de 2013.

JORGE, Tarsis Nametala Sarlo. O custeio da seguridade social. 2. ed. Rio de Janeiro: Lumen Juris, 2007.

LEMES, Alexandre Barbosa. Tutela penal da previdência social. Curitiba: Juruá, 2009.

LO MONTE, Elio. L'illecito penale tributário tra tecniche di tutela ed esigenze di reforma. Padova: CEDAM, 1996.

LOVATTO, Alecio Adão. Crimes tributários: aspectos criminais e processuais. 2. ed. rev. e ampl. Porto Alegre: Livraria do advogado, 2003.

MACIEL FILHO, Euro Bento. Crimes previdenciários: análise crítica dos delitos clássicos contra a previdência social, à luz da Lei n. 9.983, de 14.7.2000. São Paulo: Juarez de Oliveira, 2004.

MOREIRA, Vital. Economia e Constituição: para o conceito de Constituição econômica. 2. ed. Coimbra: Coimbra, 1979.

PAULSEN, Leandro. Crimes federais. São Paulo: Saraiva, 2017. 
PIMENTEL, Manoel Pedro. Apropriação indébita por mera semelhança: os crimes de apropriação indébita, previstos na legislação previdenciária. Revista dos Tribunais, ano 62, v. 451, p. 321-329, 1973.

RODRIGUES, Savio Guimarães. Bem jurídico-penal tributário: a legitimidade do sistema punitivo em matéria fiscal. Porto Alegre, Núria Fabris, 2013.

RUIVO, Marcelo Almeida. Os crimes de sonegação fiscal (arts. $1^{\circ}$ e $2^{\circ}$, Lei 8.137/90). In: RUIVO, Marcelo Almeida; BOSSA, Gisele Barra (org.). Crimes contra ordem tributária: do direito tributário ao direito penal. São Paulo: Almedina, 2019, p. 429-452.

RUIVO, Marcelo Almeida. Legislação penal e ciências criminais: por uma teoria orientador dos interesses político-criminais. Revista Brasileira de Ciências Criminais, ano 26, n. 147, p. 587-614, 2018.

SALCUNI, Giandomenico. Natura giuridica e funzioni delle soglie di punibilità nel nuovo diritto penale tributario. Rivista trimestrale di diritto penale dell'economia, Padova, v. 14, p. 131-185, jan/jun. 2001.

SALTIEL, Ramiro Gomes von. Crimes previdenciários e tecnologia: análise do discurso legislativo dos arts. 313-A e 313-B do Código Penal. In: VEIGA, Fábio da Silva; LEVATE, Luiz Gustavo; GOMES, Marcelo Kokke (dir.). Novos Métodos Disruptivos no Direito. Porto; Belo Horizonte: Instituto Iberoamericano de Estudos Jurídicos e Escola de Direito Dom Hélder, 2020, p. 76-85.

SARLET, Ingo Wolfgang. A eficácia dos direitos fundamentais: uma teoria geral dos direitos fundamentais na perspectiva constitucional. 12. ed. rev. atual. e ampl. Porto Alegre: Livraria do Advogado, 2015.

SCHMIDT, Andrei Zenkner. Direito penal econômico: parte geral. 2. ed. rev. e ampl. Porto Alegre: Livraria do Advogado, 2018.

SOUSA, Susana Aires de. Os crimes fiscais: análise dogmática e reflexão sobre a legitimidade do discurso criminalizador. Coimbra: Coimbra, 2006.

STOCO, Rui; STOCO, Tatiana de Oliveira. Crimes contra a ordem tributária. São Paulo: Revista dos Tribunais, 2016.

TORRES CADAVID, Natalia. Problemas de los delitos contra la Hacienda Pública. En particular, la responsabilidad penal del asesor fiscal. 2007. Tese (doutorado em Direito) - Facultad de Derecho, Universidad de León, León, 2007.

ZECCA, Mattia. Il diritto penale tributario tra questioni problematiche e prospettive di riforma. 2016. Tese (dottorato di ricerca in diritto ed impresa) Departimento di Giurisprudenza, Libera università degli studi sociali "Guido Carli", Roma, 2016. 